\title{
Microclimate and thermal comfort indices in silvopastoral systems under different planting directions and seasons
}

\author{
Rafael P. de Carvalho' ${ }^{1}$ Debora M. Heid², Livia M. C. Davide², Ligia M. M. da S. Piletti ${ }^{1}$, \\ Fernanda L. F. de Jesus ${ }^{3} \&$ Antonio L. Viegas Neto ${ }^{1}$
} ${ }^{1}$ Instituto Federal de Mato Grosso do Sul/Campus Ponta Porã, Ponta Porã, MS, Brasil. E-mail: rafael.carvalho@ifms.edu.br (Corresponding author) -
ORCID: 0000-0002-1412-8246; ligia.piletti@ifms.edu.br - ORCID: 0000-0002-2179-348X; antonio.viegas@ifms.edu.br - ORCID: 0000-0001-7295-3597
${ }^{2}$ Universidade Federal da Grande Dourados/Faculdade de Ciências Agrárias, Dourados, MS, Brasil. E-mail: deboraheid1@gmail.com - ORCID: 0000-
0001-6002-6120; lmcdavide@ufgd.edu.br - ORCID: 0000-0003-1609-3750
${ }^{3}$ Universidade Federal Rural da Amazônia/Departamento de Engenharia Agrícola, Tomé-Açú, AM, Brasil. E-mail: fernanda.lamede@ufrs.edu.br - ORCID:
0000-0002-9183-6326

\begin{abstract}
The orientation of tree-rows in a silvopastoral system associated with different seasons of the year allows more or less sunlight penetration, resulting in deliberate modification of the microclimate composition and thermal conditions provided to animals. In this sense, the aims of this study were to evaluate microclimatic variables and thermal comfort indices for east-west and north-south oriented silvopastoral systems, compared to unshaded systems during summer and winter. The study was conducted at the Modelo II Farm $\left(21^{\circ} 08^{\prime} \mathrm{S} 53^{\circ} 17^{\prime} \mathrm{W}\right)$ at an altitude of $354 \mathrm{~m}$. A randomized block design in scheme of split-split plots with five repetitions was adopted. Two planting directions and a control treatment (unshaded) were evaluated in the plots. Collection times were evaluated in sub-plots, and the distance from eucalyptus trees was evaluated in sub-sub-plots. Changes in the east-west and north-south planting directions did not promote changes in climate variables, nor did they change the thermal comfort indices during summer. There were differences, however, in temperature and relative humidity of the air, black globe temperature, and radiant heat load during winter. Silvopastoral systems provide improvements in the environment and, concomitantly, to the thermal comfort of animals, when compared to unshaded systems. However, thermal stress situations occur despite the presence of trees, depending on the time of the day and the distance from the rows of eucalyptus trees.
\end{abstract}

Key words: thermal stress, shading, seasons, eucalyptus

\section{Microclima e índices de conforto térmico em sistemas silvipastoris sob diferentes direções de plantio e estações}

RESUMO: O direcionamento dos renques das árvores em sistema silvipastoril, associados a diferentes estações do ano, permite maior ou menor penetração de luz solar, resultando em expressiva modificação da composição do microclima e das condições térmicas a serem propiciadas aos animais. Neste sentido, objetivou-se avaliar as variáveis microclimáticas e índices de conforto térmico em sistemas silvipastoris orientados na direção leste-oeste e norte-sul, comparados ao sistema sem sombra nas estações de verão e inverno. O estudo foi realizado na Fazenda Modelo II ( $21^{\circ} 08^{\prime} \mathrm{S} 53^{\circ} 17^{\prime} \mathrm{O}$, e altitude de $\left.354 \mathrm{~m}\right)$. O delineamento adotado foi em blocos casualizados em esquema de parcelas sub-subdivididas, com cinco repetições. Nas parcelas foram avaliadas duas direções de plantio e controle (sem sombra). Nas sub-parcelas foram avaliados os horários de coleta e nas sub-subparcelas as distâncias em relação ao renque das árvores de eucalipto. As direções lesteoeste e norte-sul não promoveram alterações nas variáveis climáticas, bem como nos índices de conforto térmico durante o verão. Entretanto, diferenciaram-se para temperatura e umidade relativa do ar, temperatura do globo negro e carga térmica radiante durante o inverno. Os sistemas silvipastoris proporcionam melhoria no ambiente e concomitantemente no conforto térmico animal quando comparados ao sistema sem sombra. Todavia, mesmo na presença de árvores, ocorrem situações de estresse térmico, dependendo do horário do dia e da distância em relação aos renques de eucalipto.

Palavras-chave: estresse térmico, sombreamento, estações, eucalipto 


\section{INTRODUCTION}

There is global concern about food production to meet the increasing demand to feed the world population, and according to Gazzoni (2017), a study conducted by the FAO estimated the need for a $70 \%$ increase in agricultural production between 2010 and 2050. This goal will only be possible by efficient use of natural resources and climate change adaption measures.

Although tropical climate countries can contribute to this increase in food production, animal production in tropical regions may be influenced by thermal stress, which may hinder expression of the full potential of animal productivity (Souza et al., 2012).

A silvopastoral system is an efficient method for the husbandry of such as bovine and smaller ruminants, and provides a more comfortable thermal environment for them that offers more favorable and less stressing conditions (Caetano \& Caetano Junior, 2015).

According to Gómez et al. (2013), the mix of trees and pasture can be prejudicial or favorable, depending on factors like the tolerance of species to shading, the amount of shading provided by the trees, and the competition among plants for water and soil nutrients. The arrangement of tree rows allows for more or less light penetration, resulting in deliberate modification of the microclimate composition of silvopastoral systems (Tonini et al., 2019).

In this sense, the aims of this study were to evaluate microclimate variables and animal thermal comfort indices in silvopastoral systems with east-west and north-south orientations, compared with unshaded systems, during summer and winter.

\section{Material ANd Methods}

The study was conducted at the Modelo II Farm $\left(21^{\circ} 08^{\prime}\right.$ $\mathrm{S} 53^{\circ} 17^{\prime} \mathrm{W}$ ) at an altitude of $354 \mathrm{~m}$, with flat to smooth and wavy relief. The farm is located in the city of Ribas do Rio Pardo (MS, Brazil), which region is characterized by a rainy tropical savannah climate, of the Aw subtype according to the Köppen climate classification system. Through historical meteorological data of the farm, the mean maximum monthly temperature is $29.1^{\circ} \mathrm{C}$, and the minimum monthly temperature is $17.7^{\circ} \mathrm{C}$. The mean annual rainfall is $1,566.7 \mathrm{~mm}$, with a well-defined dry season during the coldest months (from May to September) and a rainy season during summer (from October to March).

Two silvopastoral systems were evaluated, with east-west (SPS/EW) and north-south (SPS/NS) oriented rows, compared with the conventional, unshaded pasture system (UPS).

These silvopastoral systems were composed of eucalyptus trees (the urograndis hybrid, I-144/Acesita clone) distributed along triple rows and with the spacing $3 \times 2 \times 20 \mathrm{~m}$ (interrow, inter-row and alley spacing, respectively). The mean density was 1,489 and 1,493 trunks per hectare in SPS/EW, and SPS/NS, respectively. Both systems were implemented in December 2009 and the trees presented a mean height of 14.5 $\mathrm{m}$ and a diameter at breast height (DBH) of $12.8 \mathrm{~cm}$ in the summer of 2012. The trees had already undergone pruning management at $8.5 \mathrm{~m}$ mean height. The timber inventory estimates in the SPS/EW and SPS/NS were 251.3 and 219.5 $\mathrm{m}^{3} \mathrm{ha}^{-1}$, respectively.

The variable samplings were simultaneously performed in all treatments, in the summer and winter of 2012 and 2013, at 8 and 11 a.m., and 2 and 5 p.m.

Regarding the horizontal position from the planting direction (i.e., between eucalyptus rows) six distances spaced $4 \mathrm{~m}$ apart were used. Data collection was performed monthly, always under clear skies and on days typical of each season. The work was suspended whenever there were clouds that could intercept solar radiation.

The distance measurements were performed from the base of tree trunks on the first row bordering the pasture, measuring $1,4,8,12,16$ and $20 \mathrm{~m}$, to the base of tree trunks on the first line of the opposite row, always using the same path direction for all samples. The path direction was from south to north in $\mathrm{SPS} / \mathrm{EW}$, and from east to west in SPS/NS.

The equipment was positioned $1.50 \mathrm{~m}$ above the ground to evaluate the environment and to simulate the larger animals' back height. A parallel line was established for each distance from the tree row, where five measurements were performed $10 \mathrm{~m}$ apart, and their values were defined by the mean between the maximum and minimum values that occurred during $30 \mathrm{~s}$ of readings. The values obtained at each distance constituted, therefore, the mean of each variable. For the UPS, however, data was collected from five random points at least $10 \mathrm{~m}$ apart, respecting the same interval and collection times as with the other two systems.

Psychrometric variables were recorded using a digital hygro-thermo-anemometer-light meter $\left(\mathrm{THAL}_{00}{ }^{\circ}\right.$ ) and corresponded to air temperature (At), air relative humidity $(\mathrm{RH})$, wind speed (S) and global solar radiation (GSR). The total shading index (\% TSI) was estimated through the GSR values at the various distances from the tree rows by the adjacent unshaded pasture area's GSR: \%TSI $=[(\mathrm{GSR}(\mathrm{SPS}) /$ GSR(UPS)) $] \times 100$. The dewpoint temperature (DP), partial vapor pressure $(\mathrm{Pp})$ and enthalpy $(\mathrm{H})$ were obtained using psychrometric equations given by ASHRAE (1997).

The following thermal comfort indices were used for data interpretation: Temperature and Humidity Index (THI), Black Globe Humidity Index (BGHI) and Radiant Heat Load (RHL).

A randomized block design in scheme of split-split plots scheme with five repetitions was adopted. In plots, two planting directions in the silvopastoral systems (SPS/EW and SPS/NS) and a control (UPS) were evaluated. In the sub-plots, sampling time was distributed throughout the day ( 8 and 11 a.m., and 2 and 5 p.m.). In sub-sub-plots, the distance from a tree row was evaluated $(1,4,8,12,16$, and $20 \mathrm{~m})$. Measurements were performed in summer and winter and the means were compared using the $t$-test at $p \leq 0.05$. The results were submitted to ANOVA, and the means related to the evaluated systems were compared using Duncan's test ( $\mathrm{p} \leq 0.05)$, while the distance and time effects were evaluated using regression analysis. The choice criterion adopted was the magnitude of the regression coefficients significant at $\mathrm{p} \leq 0.05$ by the $\mathrm{t}$-test. 


\section{Results AND Discussion}

Regarding microclimate characteristics and comfort indices during summer, there was no significant difference between the two planting directions. During winter, however, there were significant differences between the two directions, resulting in greater variation of microclimate and thermal comfort by planting direction during that season (Table 1).

The results confirmed significant differences between winter and summer. This was expected due to the more intense solar radiation during the summer solstice when (compared to the winter solstice) at locations close to $23.5^{\circ} \mathrm{S}$, the width of the Sun is perpendicular to the Tropic of Capricorn.

An improvement in microclimatic was evident in the environmental conditions provided by trees in both silvopastoral systems (compared to the control), regardless of the season (Table 1). The At, Gt and S variable data obtained in the unshaded system (UPS) during summer showed mean values of 7.5, 10.6 and $59.3 \%$ above the SPS means, respectively. However, the UPS showed RH values $12.5 \%$ below the SPS means. During winter, the UPS values were 8.3\% (At), 14.5\% (Gt), and $17.2 \%$ (S) higher than those recorded in SPS, and RH was $19.8 \%$ lower in the UPS when compared to the SPS (Table 1).
The differences found among both planting orientations and seasons in this experiment are closely related to the amount of solar radiation reaching the understory of the silvopastoral systems. This varied significantly $(\mathrm{p} \leq 0.05)$ due to the distance from a tree row and the planting orientation during both seasons (Figure 1). The quadratic model provided the best explanation of variation in the global shading index of both planting orientations, although with different magnitudes of response among both planting orientations and seasons.

It was possible to verify higher shading indices among rows during winter than during summer. According to Moreira (2003), the Sun shows apparent movement from north to south during the year due to inclination of the Earth's axis towards the planet's normal plane of translation line (known as the solar declination). This results in the Sun reaching a position more to the north of the location during the southern hemisphere winter, causing an increase of the zenith angle and consequent shading among the alleys by eucalyptus trees.

Total attenuation of incident radiation was observed at even more central distances from the rows, such as 8 and $12 \mathrm{~m}$, which condition occurred mainly during the morning and late afternoon. In summer, the greater distances from the tree rows promoted lower shading percentages during the day in both of the planting orientations evaluated. This was more intense in

Table 1. Microclimatic components and thermal comfort indices according to seasons and the evaluated silvopastoral systems

\begin{tabular}{|c|c|c|c|c|c|c|c|c|}
\hline $\begin{array}{l}\text { Treatment } \\
\text { Seasons }\end{array}$ & $\begin{array}{l}\text { At } \\
\left({ }^{\circ} \mathbf{C}\right)\end{array}$ & $\begin{array}{l}\text { RH } \\
(\%)\end{array}$ & $\begin{array}{l}\text { Gt } \\
\left({ }^{\circ} \mathrm{C}\right)\end{array}$ & $\begin{array}{c}S \\
\left(m s^{-1}\right)\end{array}$ & THI & BGHI & $\begin{array}{c}\mathrm{H} \\
\left(\mathrm{kJ} \mathrm{kg}^{-1}\right)\end{array}$ & $\begin{array}{c}\text { RHL } \\
\left(\mathrm{W} \mathrm{m}^{-2}\right)\end{array}$ \\
\hline Summer/2012 & $31.7 \quad a$ & $49.2 a b$ & 38.3 a & $3.7 \mathrm{a}$ & $79.3 \quad$ a & 85.9 a & $88.2 \quad a$ & 714.2 a \\
\hline Winter/2012 & 27.6 b & $43.0 \mathrm{~b}$ & $32.7 \quad b$ & $4.4 \mathrm{a}$ & $72.9 \quad b$ & $79.1 \quad b$ & $69.1 \mathrm{~b}$ & $580.4 \quad b$ \\
\hline Summer/2013 & $30.1 \mathrm{a}$ & $53.3 \mathrm{a}$ & $36.9 \mathrm{ab}$ & $2.5 \mathrm{a}$ & $77.8 \quad a$ & $84.2 \mathrm{a}$ & 84.4 a & $663.4 a b$ \\
\hline Winter/2013 & $26.3 \mathrm{~b}$ & $43.6 \mathrm{~b}$ & $31.3 \mathrm{~b}$ & $2.8 \mathrm{a}$ & $71.4 \mathrm{~b}$ & 77.2 b & $66.6 \mathrm{~b}$ & 589.9 b \\
\hline SPS & \multicolumn{8}{|c|}{ Summer } \\
\hline SPS/EW & 30.9 b & $49.7 \quad a$ & $37.3 \mathrm{~b}$ & $3.3 \mathrm{a}$ & $78.1 \quad b$ & 86.9 b & $84.5 b$ & $702.4 \quad b$ \\
\hline SPS/NS & $30.1 \quad b$ & 51.5 a & $36.1 \quad b$ & $2.6 \mathrm{a}$ & 77.8 b & $85.5 \quad b$ & 83.9 b & 667.2 b \\
\hline UPS & $32.8 \quad \mathrm{a}$ & $44.3 \mathrm{~b}$ & $40.6 \quad \mathrm{a}$ & $4.7 \mathrm{a}$ & $81.2 \mathrm{a}$ & $89.4 \quad \mathrm{a}$ & $92.8 \mathrm{a}$ & $766.7 \mathrm{a}$ \\
\hline & \multicolumn{8}{|c|}{ Winter } \\
\hline SPS/EW & $24.8 \mathrm{C}$ & $46.1 \mathrm{C}$ & $29.1 \mathrm{C}$ & $2.7 \mathrm{a}$ & $71.8 \mathrm{~b}$ & $79.1 \quad b$ & $66.8 \mathrm{~b}$ & 577.6 C \\
\hline SPS/NS & 26.9 b & $41.2 \mathrm{~b}$ & $32.4 \mathrm{~b}$ & $3.1 \mathrm{a}$ & $72.4 \quad b$ & $78.8 \quad b$ & $68.7 \mathrm{~b}$ & 592.0 b \\
\hline UPS & $28.0 \mathrm{a}$ & $35.0 \mathrm{a}$ & $35.2 \mathrm{a}$ & $3.4 \mathrm{a}$ & $75.8 \quad \mathrm{a}$ & $81.6 \mathrm{a}$ & $72.7 \mathrm{a}$ & $686.0 \mathrm{a}$ \\
\hline Significance & \multicolumn{8}{|c|}{ Summer } \\
\hline Orientation (Orient) & ns & ns & ns & ns & ns & ns & ns & ns \\
\hline Time (Time) & \#\# & \# & \#\# & \# & \# & \#\# & \# & \#\# \\
\hline Orient $x$ Time & ns & ns & ns & ns & ns & ns & ns & ns \\
\hline Distance (Dis) & \#\# & \# & \# & ns & \# & \# & \# & \# \\
\hline Orient $x$ Dis & * & ns & * & ns & ns & * & ns & * \\
\hline Time $x$ Dis & * & * & $\star \star$ & ns & ns & ** & ns & ** \\
\hline Orient $\mathrm{x}$ Time $\mathrm{x}$ Dis & ns & ns & ns & ns & ns & ns & ns & ns \\
\hline $\mathrm{CV}_{\text {plot }}(\%)$ & 7.98 & 13.90 & 18.72 & 33.42 & 7.98 & 12.93 & 16.12 & 23.06 \\
\hline $\mathrm{CV}_{\text {sub-plot }}(\%)$ & 20.91 & 28.10 & 21.98 & 50.89 & 11.98 & 15.92 & 7.91 & 20.95 \\
\hline $\mathrm{CV}_{\text {sub-sub-plot }}(\%)$ & 8.32 & 6.98 & 14.26 & 14.18 & 6.98 & 9.23 & 2.29 & 10.22 \\
\hline Significance & \multicolumn{8}{|c|}{ Winter } \\
\hline Orientation (Orient) & * & * & * & ns & ns & ns & ns & * \\
\hline Time (Time) & \#\# & \# & \#\# & \# & \# & \#\# & \# & \#\# \\
\hline Orient $x$ Time & $\mathrm{ns}$ & ns & ns & ns & ns & ns & ns & ns \\
\hline Distance (Dis) & \# & \# & \# \# & ns & \#\# & \#\# & \#\# & \#\# \\
\hline Orient x Dis & $\star \star$ & $\star \star$ & * & ns & $\star$ & $\star$ & $\star$ & * \\
\hline Time $x$ Dis & * & * & * & ns & * & * & * & * \\
\hline Orient $\mathrm{x}$ Time $\mathrm{x}$ Dis & ns & ns & ns & ns & ns & ns & ns & ns \\
\hline $\mathrm{CV}_{\text {plot }}(\%)$ & 5.87 & 11.87 & 15.90 & 41.65 & 5.24 & 9.42 & 10.32 & 26.91 \\
\hline $\mathrm{CV}_{\text {sub-plot }}(\%)$ & 19.40 & 33.80 & 20.40 & 75.91 & 10.41 & 11.92 & 6.91 & 21.65 \\
\hline $\mathrm{CV}_{\text {sub-sub-plot }}(\%)$ & 7.94 & 3.87 & 13.93 & 20.10 & 3.98 & 4.32 & 4.12 & 13.72 \\
\hline
\end{tabular}

At - Air temperature; RH - Air relative humidity; Gt - Black globe temperature; S - Wind speed; THI - Temperature and humidity index; BGHI - Black globe humidity index H Enthalpy; RHL - Radiant heat load; SPS/NS - Silvopastoral system with a north-south planting orientation; SPS/EW - Silvopastoral system with an east-west planting orientation; UPS - Unshaded pastoral system; Means followed by the same letter in columns, for seasons and for systems, are not statistically different by the $t$-test and Duncan's test ( $\mathrm{p} \leq 0.05$ ), respectively. Ns, ${ }^{*}, * *, \#, \# \#$ - non-significant, significant at $\mathrm{p} \leq 0.05$ and $\mathrm{p} \leq 0.01$ by the t-test, significant polynomial regression at $\mathrm{p} \leq 0.05$ and $\mathrm{p} \leq 0.01$ by the F-test, respectively. 
A.

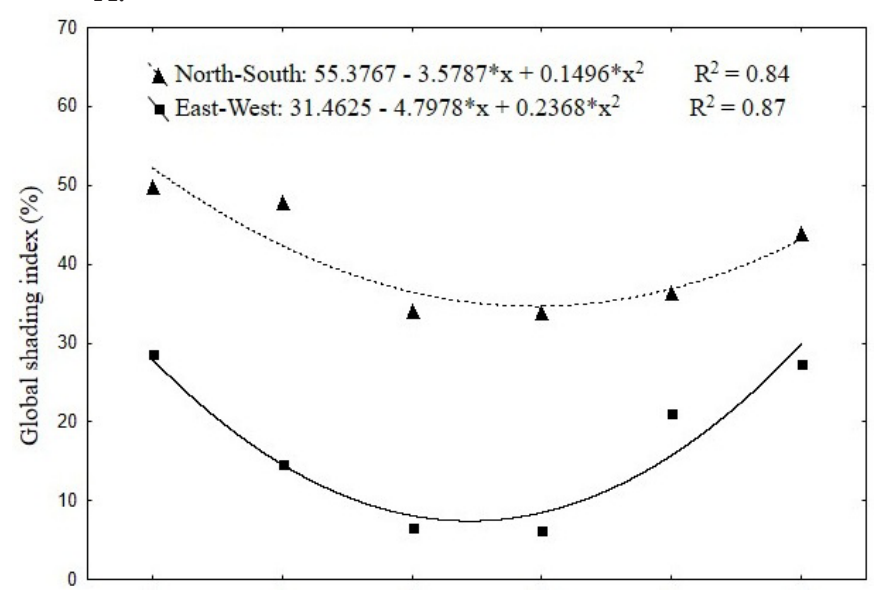

B.

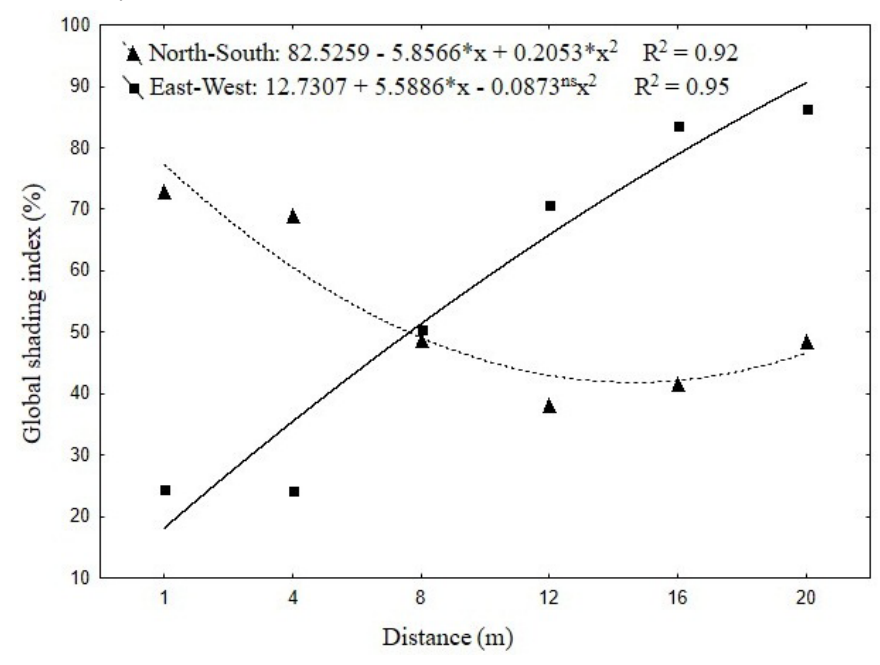

${ }^{n s}$ Non-significant; ${ }^{*}$ Significant at $\mathrm{p} \leq 0.05$ by the F-test

Figure 1. Global shading index in silvopastoral systems with eastwest and north-south orientations, as function of the distance from eucalyptus rows, during summer (A) and winter (B)

the north-south orientation (mean shading index of 40.5\%), than the $17.5 \%$ recorded in the east-west orientation (Figure 1). However, inversion of the mean shading percentage was verified during winter: $57 \%$ in the east-west orientation and $52.1 \%$ in the north-south orientation.
Paciullo et al. (2011) asserted that there is a greater possibility of understory shading when topographic characteristics demand planting in the north-south direction. This assertion was only partly corroborated by the results in this study because such a condition was verified only during summer. In contrast, the opposite situation occurred during winter.

A particularly distinct global shading index effect was observed during winter in the east-west orientation concerning the distance from the tree rows. The typical pattern was shown with both orientations during summer and by the north-south orientation during winter. The curve demonstrates a constant and high shading percentage during the day at the distances of 12,16 and $20 \mathrm{~m}$ (i.e., those oriented towards the north received less radiant energy than those oriented towards the south, as represented by 1,4 and $8 \mathrm{~m}$ distances). This effect was the most accountable for the significant differences reached in the variable data evaluated among seasons and planting orientations.

These results corroborate those of Oliveira et al. (2014), who noticed that eucalyptus rows had a higher shading percentage during autumn and winter, with higher shading concentration in the center of tree inter-row regions. During spring and summer, less paddock shading was observed; sunlight was mostly visible in the paddock inter-rows and shadows were observed closer to the tree rows.

Interactions observed during summer between the distance and system factors for At, BGHI and RHL were evidenced by the inversion of values at a distance of $20 \mathrm{~m}$ and their increases in the north-south orientation (Table 2). This behavior is related to higher radiant energy rates that reach the east side of the north-south orientation during the late afternoon hours when the incident angle of the Sun's rays, or zenith angle, is larger due to the lower sun elevation during these times.

The significant differences in At obtained among the eastwest and the north-south orientations at the shortest distances from the tree rows $(1,4$ and $20 \mathrm{~m}$ ) were caused by the higher shading indices present at these distances in the north-south orientation during summer. The Gt, BGHI and RHL variables were also capable of distinguishing orientations, however, only at closer distances (i.e., those distances facing west from

Table 2. Unfolding of the systems $\mathrm{x}$ distances interaction related to air temperature (At), black globe temperature (Gt), black globe humidity index (BGHI), enthalpy $(\mathrm{H})$ and radiant heat load (RHL) during summer

\begin{tabular}{|c|c|c|c|c|c|c|c|c|c|c|c|c|c|c|}
\hline \multirow{2}{*}{ Orientation } & \multicolumn{12}{|c|}{ Distance (m) } & \multirow{2}{*}{ Regression } & \multirow{2}{*}{$\mathrm{R}^{2}$} \\
\hline & 1 & & 4 & & & 8 & & 12 & 1 & & 20 & 0 & & \\
\hline \multicolumn{15}{|c|}{ Air temperature $\left({ }^{\circ} \mathrm{C}\right)$} \\
\hline SPS/EW & 29.6 & $\mathrm{a}$ & 31.9 & $\mathrm{a}$ & 31.8 & a & 31.6 & a & 30.7 & a & 28.3 & $b$ & $y=29.387+0.5896^{\star} x-0.0322^{* *} x^{2}$ & 0.93 \\
\hline SPS/NS & 28.6 & b & 29.7 & b & 30.5 & $\mathrm{a}$ & 30.8 & a & 30.3 & $\mathrm{a}$ & 30.2 & $\mathrm{a}$ & $y=28.352+0.3699^{* *} x-0.0143^{*} x^{2}$ & 0.91 \\
\hline \multicolumn{15}{|c|}{ Black globe temperature $\left({ }^{\circ} \mathrm{C}\right)$} \\
\hline SPS/EW & 37.9 & a & 39.7 & a & 40.4 & a & 39.9 & a & 38,5 & $a$ & 36.0 & a & $y=37.44+0.6545^{\star \star} x-0.0365^{\star \star} x^{2}$ & 0,99 \\
\hline SPS/NS & 33.3 & $\mathrm{~b}$ & 33.8 & $b$ & 37.3 & $b$ & 37.4 & $\mathrm{a}$ & 37.8 & $\mathrm{a}$ & 37.7 & $\mathrm{a}$ & $y=32.252+0.7036^{*} x-0.0217^{n s} x^{2}$ & 0.92 \\
\hline \multicolumn{15}{|c|}{ Black globe humidity index (BGHI) } \\
\hline SPS/EW & 87.0 & $\mathrm{a}$ & 88.9 & $\mathrm{a}$ & 89.8 & a & 89.1 & $\mathrm{a}$ & 87.9 & $\mathrm{a}$ & 85.2 & $\mathrm{a}$ & $y=86.5+0.7007^{\star *} x-0.0384^{* \star} x^{2}$ & 0.98 \\
\hline SPS/NS & 82.4 & b & 83.0 & b & 86.5 & b & 86.6 & a & 87.1 & $\mathrm{a}$ & 86.9 & $\mathrm{a}$ & $y=81.344+0.7253^{\star} x-0.0225^{n s} x^{2}$ & 0.92 \\
\hline \multicolumn{15}{|c|}{ Enthalpy $(\mathrm{H})$} \\
\hline SPS & 82.8 & & 83.7 & & 84.8 & & 84.8 & & 84.6 & & 84.4 & & $y=82.501+0.3647^{\star *} x-0.0138^{*} x^{2}$ & 0.95 \\
\hline \multicolumn{15}{|c|}{ Radiant heat load (RHL) } \\
\hline SPS/EW & 726 & $\mathrm{a}$ & 795 & $\mathrm{a}$ & 801 & a & 762 & a & 755 & a & 658 & $\mathrm{a}$ & $y=720.2+18.152^{\star} x-1.0573^{\star} x^{2}$ & 0.90 \\
\hline SPS/NS & 590 & b & 607 & $b$ & 713 & b & 703 & b & 695 & $\mathrm{a}$ & 685 & $\mathrm{a}$ & $y=559.59+21.913^{*} x-0.7959^{n s} x^{2}$ & 0.86 \\
\hline
\end{tabular}

Means followed by the same lowercase letter in columns are not statistically different by the $t$-test for distance factors $(p \leq 0.05)$. ${ }^{n s},{ }^{*},{ }^{* *}-$ non-significant, significant at $p \leq 0.05$ and $\mathrm{p} \leq 0.01$ by the F-test, respectively. SPS/NS - Silvopastoral system with a north-south planting orientation; SPS/EW - Silvopastoral system with an east-west planting orientation; SPS - Silvopastoral systems 
the north-south orientation, which received lower irradiance levels, compared to the south side in the east-west orientation) (Table 2).

All the variable data of the UPS evaluated for the time factor during summer were significantly different from those for the SPS, mainly during the afternoon ( 2 and 5 p.m.). The exception was the RHL, which was distinguishable for a longer time among the systems from 11 a.m. to 5 p.m. during both seasons studied (Table 3). During winter, however, the THI, BGHI and $\mathrm{H}$ indices distinguished the two systems between 8 a.m. and 2 p.m. (Table 5). This is due to the greater heat difference among the SPS and the UPS at these times. During the morning, the sunlight takes longer to heat the SPS environment than for the UPS. This is due to the influence of trees that absorb part of the direct radiation for photosynthesis and because of the greater zenithal angle during these seasons.

The means of the enthalpy data observed were significantly inferior in the SPS when compared to the UPS at 2 and 5 p.m. during summer, and between 8 a.m. and 2 p.m. during winter. These results diverge from the results found by Gurguel et al. (2012), when evaluating the thermal quality of the natural shading provided by three different tree species (Copaifera

Table 3. Behavior of silvopastoral systems (SPS) compared with unshaded pasture systems (UPS) for the time factor, related to black globe temperature (Gt), wind speed (S), temperature and humidity index (THI), black globe humidity index (BGHI), enthalpy and radiant heat load (RHL)

\begin{tabular}{|c|c|c|c|c|c|c|c|c|c|}
\hline \multirow{2}{*}{ Systems } & \multicolumn{7}{|c|}{ Time (h) } & \multirow{2}{*}{ Regression } & \multirow{2}{*}{$\mathbf{R}^{2}$} \\
\hline & \multicolumn{2}{|c|}{8} & \multirow{2}{*}{\multicolumn{2}{|c|}{11}} & 14 & \multicolumn{2}{|c|}{17} & & \\
\hline \multicolumn{8}{|c|}{ Black globe temperature $\left({ }^{\circ} \mathrm{C}\right)$} & & \\
\hline SPS & 25.4 & a & 40.3 & $\mathrm{a}$ & $44.3 \mathrm{~b}$ & 37.7 & b & $y=-2.5531+33.6056^{\star \star} x-5.8639^{\star \star} x^{2}$ & 0.99 \\
\hline UPS & 27.8 & a & 43.5 & $\mathrm{a}$ & $48.9 \mathrm{a}$ & 44.3 & $\mathrm{a}$ & $y=-8.7288+44.9075^{* *} x-8.6609^{* *} x^{2}$ & 0.99 \\
\hline \multicolumn{10}{|c|}{ Wind speed $\left(\mathrm{m} \mathrm{s}^{-1}\right)$} \\
\hline SPS & 0.17 & a & 2.87 & $b$ & $3.08 \mathrm{~b}$ & 1.92 & $\mathrm{a}$ & $y=-15.812+2.8626^{n s} x-0.1072^{n s} x^{2}$ & 0.98 \\
\hline UPS & 0.24 & $\mathrm{a}$ & 6.89 & $\mathrm{a}$ & $5.35 \quad \mathrm{a}$ & 3.06 & $\mathrm{a}$ & $y=-35.007+6.439^{n s} x-0.2483^{n s} x^{2}$ & 0.88 \\
\hline \multicolumn{10}{|c|}{ Temperature and humidity index (THI) } \\
\hline SPS & 71.2 & a & 79.2 & a & 83.2 b & 78.1 & b & $y=14.869+9.9206^{n s} x-0.3639^{n 5} x^{2}$ & 0.98 \\
\hline UPS & 73.5 & $\mathrm{a}$ & 81.0 & $\mathrm{a}$ & $87.7 \mathrm{a}$ & 81.3 & $a$ & $y=12.347+10.656^{n s} x-0.3861^{n s} x^{2}$ & 0.92 \\
\hline \multicolumn{10}{|c|}{ Black globe humidity index (BGHI) } \\
\hline SPS & 73.7 & a & 90.0 & a & $95.2 \mathrm{~b}$ & 90.2 & $\mathrm{~b}$ & $y=-21.308+16.615^{\star \star} x-0.5917^{\star \star} x^{2}$ & 0.99 \\
\hline UPS & 75.6 & a & 92.6 & a & $99.7 \quad$ a & 94.9 & $\mathrm{a}$ & $y=-24.189+17.306^{\star} x-0.6056^{\star} x^{2}$ & 0.99 \\
\hline \multicolumn{10}{|c|}{ Enthalpy $(\mathrm{H})$} \\
\hline SPS & 71.9 & a & 87.2 & $\mathrm{a}$ & $93.6 \mathrm{~b}$ & 84.8 & $\mathrm{~b}$ & $y=-31,486+18,239^{n s} x-0,6694^{n s} x^{2}$ & 0.99 \\
\hline UPS & 71.5 & a & 92.8 & $a$ & $101.6 \mathrm{a}$ & 92.2 & $\mathrm{a}$ & $y=-63,669+23,683^{\star} x-0,8528^{*} x^{2}$ & 0.99 \\
\hline \multicolumn{10}{|c|}{ Radiant heat load (RHL) } \\
\hline SPS & 464 & a & 798 & b & $901 \mathrm{~b}$ & 670 & $\mathrm{~b}$ & $y=-1867.9+416.39^{*} x-15.694^{*} x^{2}$ & 0.99 \\
\hline UPS & 471 & a & 921 & $\mathrm{a}$ & $984 \quad \mathrm{a}$ & 1027 & $\mathrm{a}$ & $y=-655.22+42.111^{*} x-1.1111 * x^{2}$ & 0.99 \\
\hline
\end{tabular}

Means followed by the same lowercase letter in columns are not statistically different by Duncan's test for the time factor $(\mathrm{p} \leq 0.05)$. ${ }^{\mathrm{ns}},{ }^{*},{ }^{* *}-$ non-significant, significant at $\mathrm{p} \leq 0.05$ and $\mathrm{p} \leq 0.01$ by the F-test, respectively. UPS - Unshaded pastoral systems; SPS - Silvopastoral systems

Table 4. Unfolding of the system $\mathrm{x}$ distance interaction concerning air temperature (At), air relative humidity (RH), black globe temperature (Gt), temperature and humidity index (THI), black globe humidity index (BGHI), enthalpy (H) and radiant heat load (RHL) during winter

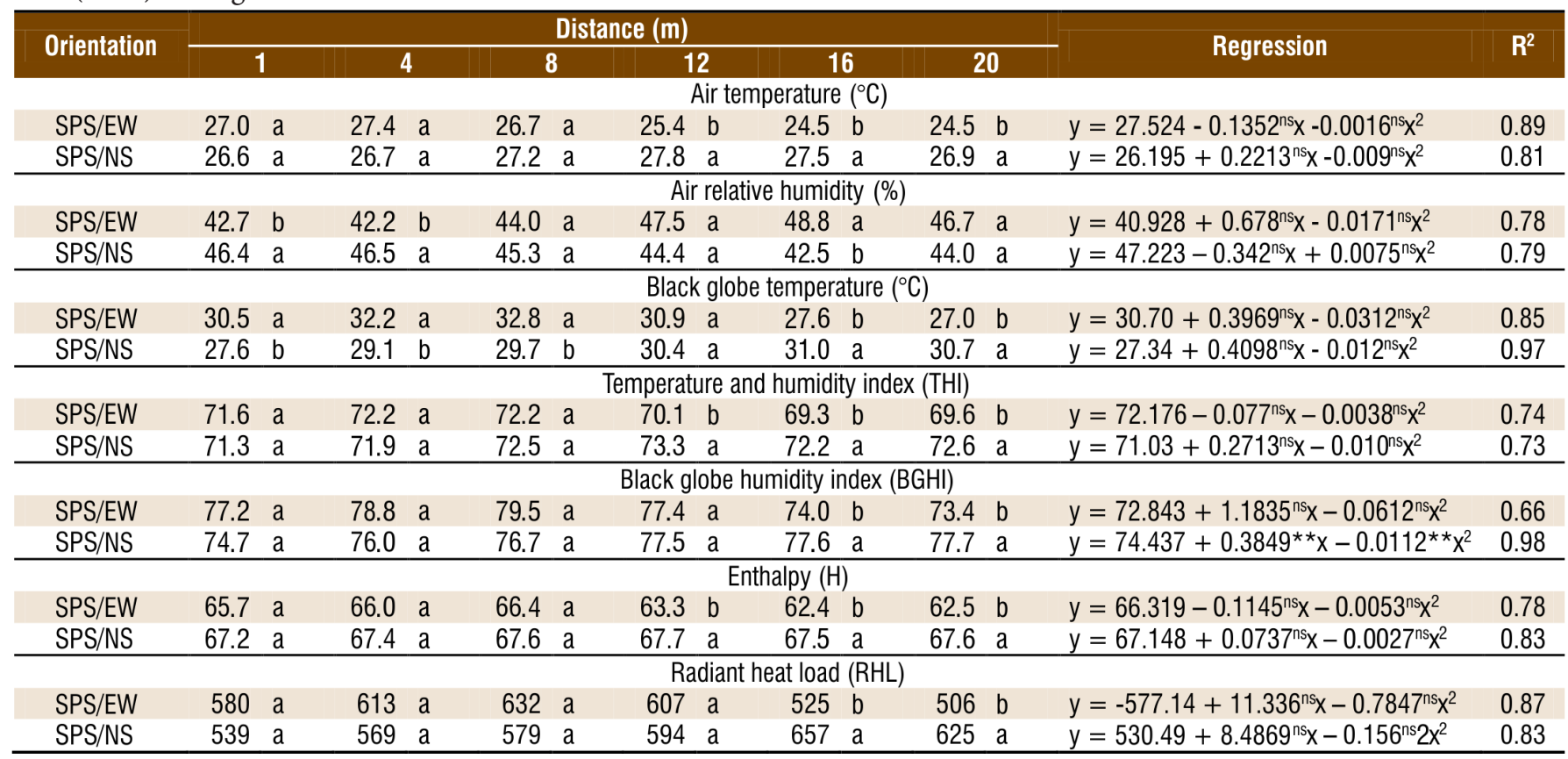

Means followed by the same lowercase letter in columns are not statistically different by the t-test for distance factor $(p \leq 0.05)$. ${ }^{\text {ns }},{ }^{*}$, ** - non-significant, significant at $p \leq 0.05$ and $\mathrm{p} \leq 0.01$ by the F-test, respectively. SPS/NS - Silvopastoral system with a north-south planting orientation; SPS/EW - Silvopastoral system with an east-west planting orientation; SPS - Silvopastoral systems 
Table 5. Behavior of silvopastoral systems (SPS) compared to the unshaded control system (UPS) according to the time, related to air temperature (At), air relative humidity $(\mathrm{RH})$, black globe temperature $(\mathrm{Gt})$, wind speed (S), temperature and humidity index (THI), black globe humidity index (BGHI), enthalpy $(\mathrm{H})$ and radiant heat load (RHL) during winter

\begin{tabular}{|c|c|c|c|c|c|c|c|c|c|}
\hline \multirow{2}{*}{ Systems } & \multicolumn{7}{|c|}{ Time (h) } & \multirow{2}{*}{ Regression } & \multirow{2}{*}{$\mathbf{R}^{2}$} \\
\hline & \multicolumn{2}{|c|}{8} & \multicolumn{2}{|c|}{11} & \multirow{2}{*}{\multicolumn{3}{|c|}{$\begin{array}{l}14 \\
\text { Air temperature }\left({ }^{\circ} \mathrm{C}\right)\end{array}$}} & & \\
\hline & & & & & & & & & \\
\hline SPS & 17.4 & a & 29.2 & a & $31.8 \mathrm{~b}$ & 27.7 & a & $y=-51.475+12.158^{\star} x-0.4417^{\star} x^{2}$ & 0.99 \\
\hline UPS & 18.5 & a & 29.9 & $\mathrm{a}$ & $34.3 \mathrm{a}$ & 28.5 & a & $y=-55.811+13.091^{\star} x-0.4778^{\star} x^{2}$ & 0.99 \\
\hline \multicolumn{10}{|c|}{ Air relative humidity (\%) } \\
\hline SPS & 80.7 & a & 33.2 & a & $27.1 \mathrm{a}$ & 39.3 & a & $y=339.83-45.802^{n s} x+1.6583^{n s} x^{2}$ & 0.98 \\
\hline UPS & 69.9 & b & 29.4 & a & $21.8 \mathrm{~b}$ & 30.9 & b & $y=289.69-38.598^{n s} x+1.3778^{n s} x^{2}$ & 0.99 \\
\hline \multicolumn{10}{|c|}{ Black globe temperature $\left({ }^{\circ} \mathrm{C}\right)$} \\
\hline SPS & 19.6 & b & 34.3 & a & $38.2 \mathrm{~b}$ & 27.8 & a & $y=-82.997+18.381^{\star} x-0.6972^{\star} x^{2}$ & 0.99 \\
\hline UPS & 26.3 & a & 38.8 & $\mathrm{a}$ & $44.1 \mathrm{a}$ & 28.0 & $\mathrm{a}$ & $y=-85.228+20.208^{n s} x-0.794^{n s} 4 x^{2}$ & 0.95 \\
\hline \multicolumn{10}{|c|}{ Wind speed $\left(\mathrm{m} \mathrm{s}^{-1}\right)$} \\
\hline SPS & 0.11 & a & 3.05 & b & $3.65 \mathrm{~b}$ & 1.20 & a & $y=-21.32+3.8721^{\star} x-0.1497^{\star} x^{2}$ & 0.99 \\
\hline UPS & 0.10 & a & 6.94 & $\mathrm{a}$ & $6.83 \mathrm{a}$ & 2.18 & $\mathrm{a}$ & $y=-44.821+8.1835^{\star} x-0.3192^{\star} x^{2}$ & 0.99 \\
\hline \multicolumn{10}{|c|}{ Temperature and humidity index (THI) } \\
\hline SPS & 60.9 & b & 73.5 & b & $78.0 \mathrm{~b}$ & 74.0 & a & $y=-13.511+12.988^{\star *} x-0.4611^{\star *} x^{2}$ & 0.99 \\
\hline UPS & 63.8 & $\mathrm{a}$ & 76.1 & $\mathrm{a}$ & $81.3 \mathrm{a}$ & 75.9 & $\mathrm{a}$ & $y=-14.308+13.675^{\star} x-0.4917^{\star} x^{2}$ & 0.99 \\
\hline \multicolumn{10}{|c|}{ Black globe humidity index (BGHI) } \\
\hline SPS & 65.8 & b & 81.1 & b & $85.5 \mathrm{~b}$ & 74.5 & a & $y=-41.914+19.281^{\star} x-0.7306^{*} x^{2}$ & 0.99 \\
\hline UPS & 73.4 & $\mathrm{a}$ & 86.3 & $\mathrm{a}$ & $92.0 \mathrm{a}$ & 74.8 & $\mathrm{a}$ & $y=-43.736+21.233^{n s} x-0.8361^{n s} x^{2}$ & 0.94 \\
\hline \multicolumn{10}{|c|}{ Enthalpy (H) } \\
\hline SPS & 53.4 & b & 67.9 & b & $73.9 \mathrm{~b}$ & 68.1 & $\mathrm{a}$ & $y=-36.814+15.767^{*} x-0.5639 x^{2}$ & 0.99 \\
\hline UPS & 59.5 & $\mathrm{a}$ & 73.3 & $\mathrm{a}$ & $80.0 \mathrm{a}$ & 70.1 & $\mathrm{a}$ & $y=-46.831+18.931^{n s} x-0.7139^{n s} x^{2}$ & 0.97 \\
\hline \multicolumn{10}{|c|}{ Radiant heat load (RHL) } \\
\hline SPS & 436 & a & 686 & b & $751 \mathrm{~b}$ & 469 & $\mathrm{~b}$ & $y=-1625.6+374.91^{n s} x-14.778^{n s} x^{2}$ & 0.98 \\
\hline UPS & 494 & $\mathrm{a}$ & 903 & $\mathrm{a}$ & $955 \mathrm{a}$ & 441 & $\mathrm{a}$ & $y=-2974.8+637.41^{n s} x-25.639^{n s} x^{2}$ & 0.98 \\
\hline
\end{tabular}

Means followed by the same lowercase letter in columns are not statistically different per the Duncan's test for the time factor (p $\leq 0.05)$. ns, ${ }^{*},{ }^{* *}-$ non-significant, significant at $\mathrm{p} \leq$ 0.05 and $\mathrm{p} \leq 0.01$ by the F-test, respectively. UPS - Unshaded pastoral systems; SPS - Silvopastoral systems

langsdorffi, Pithecellobium incuriale, and Qualea jundiahy) in the city of Botucatu (SP, Brazil). When the $\mathrm{H}$ values were observed to be higher under tree shadows than in the open at all the times studied, those researchers argued that the temperature was higher in the open due to the microclimate generated, a condition not observed in this study.

The bovine thermal comfort zone (thermoneutrality) is relatively narrow $\left(-1\right.$ to $\left.16^{\circ} \mathrm{C}\right)$ with a critical limit above $27^{\circ} \mathrm{C}$ for European breeds and between 10 and $27^{\circ} \mathrm{C}$ for zebu with a critical limit above $35^{\circ} \mathrm{C}$ (Furtado et al., 2012). The high At indices observed in this region represent a great challenge for these animals, for which they must develop heat dissipation mechanisms.

In general, the means observed for $\mathrm{RH}$ and At were out of the bovine comfort zone as considered by Santos et al. (2005) in both of the systems evaluated. In contrast, the region showed a few desirable situations, as seen during the hottest hours of the day (from 11 a.m. to 2 p.m.), when the $\mathrm{RH}$ mean reached values between 43 and 46\% during summer in SPS and between 21 and $29 \%$ in UPS at a mean wind speed (S) up to $5.8 \mathrm{~m} \mathrm{~s}^{-1}$, which favored heat loss by evaporative processes.

The wind speed was similar at all times in the SPS/EW and SPS/NS ( $p>0.05$ ) during both of the seasons evaluated (Table $1)$. The SPS, however, showed significantly lower $S$ values when compared to the control (Tables 3 and 5). In both seasons, the highest means of S occurred at 11 a.m. and 2 p.m., times when the systems were also statistically different (while being similar at the other times) (see Tables 3 and 5). Souza et al. (2010) evaluated the effect of different heights (18 and $28 \mathrm{~m}$ ) of eucalyptus trees in rows in silvopastoral systems. They observed that the reduction of $S$ by a barrier intensifies as $S$ increases, but the reduction variability concomitantly increases. That fact was corroborated in this study and related to high coefficients of variation $(\mathrm{CV})$ obtained for this variable (Table 1).

Another fact related to the observed variability of the $S$ values obtained, refers to the changes in wind direction and speed due to the surface roughness resulting from obstacles and the vertical distance of the measurement above the surface. Greater field friction occurs closer to the surface, which decelerates the movement and reduces the air velocity. This drag imposed by the surface causes faster air currents to be deflected downwards, creating a sudden air surge near the ground (Angelocci et al., 1995).

The mean black globe temperature (Gt) was significantly higher during summer $\left(38.3^{\circ} \mathrm{C}\right)$ when compared to the winter $\left(32.7^{\circ} \mathrm{C}\right)$ (Table 1$)$. The Gt remained regular in systems containing eucalyptus trees and reached critical levels at some times of the day. This is according to the classification system given by Ferreira et al. (2006), who considers a Gt of $23{ }^{\circ} \mathrm{C}$ a thermal comfort condition and $44{ }^{\circ} \mathrm{C}$ a severe heat stress condition.

There was a significant difference in THI between SPS and UPS during both of the seasons evaluated, and it remained higher in the UPS when compared to the SPS at 2 and 5 p.m. during summer and at 8 a.m., 11 a.m. and 2 p.m. during winter (Table 5). This effect is due to the influence of the RH on the THI because the SPS conserves RH levels longer during winter in the morning, and the lowest $\mathrm{RH}$ levels were verified at 2 p.m. during summer. There were no THI differences $(p>0.05)$ among the systems at other times.

Significant differences were observed for the black globe humidity index (BGHI) among the seasons during the two years 
evaluated (Table 1): it remained higher in the summer (85.05) than in the winter (78.15). The BGHI was different between the two planting orientations. During summer, the SPS/EW showed higher means at 1, 4 and $8 \mathrm{~m}$ distances, while the SPS/NS showed higher values at 12,16 and $20 \mathrm{~m}$ distances during winter (Tables 2 and 4). This BGHI variation (verified among distances from the eucalyptus rows) demonstrates similarities with other variables (At, Gt, THI and RHL), which will influence animal behavior in the SPS. These include changes in such as the usual attitude patterns, movement and food ingestion, according to alternation of the shading in the systems.

The RHL was significantly affected by season, location and sampling time. A $15 \%$ difference was verified among seasons ( $\mathrm{p} \leq 0.01$ ) with mean values of 688.8 and $585.1 \mathrm{~W} \mathrm{~m}^{-2}$ for summer and winter, respectively. This was the only thermal comfort index used that was capable of distinguishing the east-west and north-south orientations in SPS during winter, as well as distinguishing the At, $\mathrm{RH}$ and Gt variables. The same were not verified in summer (Table 1).

By comparing the SPS with the UPS, lower mean values were verified in SPS, with decreases reaching $12.9 \%$ during summer (SPS/NS) and $24.6 \%$ during winter (SPS/EW). Silva et al. (2012) verified that shading by Acacia holosericea trees provided a $26 \%$ reduction of the heat load on animals when compared with the unshaded treatment (in the open). The lower rates of decrease verified in this study are possibly due to the complete characterization of the means so as to apply to rows and not only to areas under the treetops.

\section{Conclusions}

1. The east-west and north-south row orientations do not promote alterations in climate variables, nor in the thermal comfort indices during summer. However, they do change the air temperature (At), relative air humidity $(\mathrm{RH})$, black globe temperature (Gt) and radiant heat load (RHL) during winter.

2. The silvopastoral systems (SPS) provide concomitant improvements in both the environment and in thermal comfort when compared to the unshaded system. Even with the presence of trees, however, thermal stress situations occur depending on the time of the day and the distance from the rows of eucalyptus trees.

3. The temperature and humidity index (THI), black globe humidity index (BGHI) and enthalpy $(\mathrm{H})$ data demonstrate the same sensitivity in their distinction of the evaluated environments and times; however, differentiation occurs at 2 and 5 p.m. during summer and at 8 a.m. and 2 p.m. during winter.

4. The presence of trees improves the environmental conditions, according to the RHL index, which enables differentiation of the environmental conditions at 11 a.m., and at 2 and 5 p.m., during both of the seasons evaluated.

\section{Literature Cited}

Angelocci, L. R.; Wiendl, F. W.; Arruda, H. V. de. Monthly chances of gusts in the Piracicaba region - SP. In: Congresso Brasileiro de Agrometeorologia, 9, 1995, Campina Grande. Anais...Campina Grande: SBA, 1995. CD-Rom
ASHRAE - American Society of Heating, Refrigerating and AirConditioning Engineers. Ashrae Handbook: Fundamentals. Georgia: ASHRAE, 1997. 576p.

Caetano, G. A. de O.; Caetano Júnior, M. B. The silvopastoral's system influence on heifers' puberty. Revista PUBVET, v.9, p.232-239, 2015. https://doi.org/10.22256/pubvet.v9n5.232-239

Ferreira, F.; Pires, M. F. A.; Martinez, M. L.; Coelho, S. G.; Carvalho, A. U.; Ferreira, P. M.; Facury Filho, E. J.; Campos, W. E. Physiologic parameters of crossbred cattle subjected to heat stress. Arquivo Brasileiro de Medicina Veterinária e Zootecnia, v.58, p.1-9, 2006. https://doi.org/10.1590/S0102-09352006000500005

Furtado, D. A.; Peixoto, A. P.; Regis, J. E. F.; Nascimento, J. W. B. do; Araujo, T. G. P.; Lisboa, A. C. C. Thermoregulation and performance of Sind and Guzera young bulls in 'Agreste' region of Paraiba state. Revista Brasileira de Engenharia Agrícola e Ambiental, v.16, p.10221028, 2012. https://doi.org/10.1590/S1415-43662012000900014

Gazzoni, D. L. How to feed 10 billion citizens in the 2050s? Ciência e Agricultura, v.68, p.33-38, 2017. https://doi.org/10.21800/231766602017000400012

Gómez S.; Guenni, O.; Bravo de Guenni, L. Growth, leaf photosynthesis and canopy light use efficiency under differing irradiance and soil $\mathrm{N}$ supplies in the forage grass Brachiaria decumbens Stapf. Grass and Forage Science, v.68, p.395-407, 2013. https://doi.org/10.1111/gfs.12002

Gurguel, E. M.; Seraphim, O. J.; Silva, I. J. O. da. Method of bioclimatic evaluation of trees shade quality targeting the animal thermal comfort. Revista Energia na Agricultura, v.27, p.20-34, 2012. https://doi.org/10.17224/EnergAgric.2012v27n2p20-34

Moreira, J. L. K. The shadows cast by buildings and towers in cities and by montains in the countryside. Revista Brasileira de Ensino de Física, v.25, p.62-73, 2003. https://doi.org/10.1590/S180611172003000100008

Oliveira, C. C. de; Villela, S. D. J.; Almeida, R. G. de; Alves, F. V.; Behling Neto, A.; Martins, P. G. M. de A. Performance of Nellore heifers, forage mass, and structural and nutritional characteristics of Brachiaria brizantha grass in integrated production systems. Tropical Animal Health and Production, v.46, p.167-172, 2014. https://doi.org/10.1007/s11250-013-0469-1

Paciullo, D. S. C.; Gomide, C. A. M.; Castro, C. R. T. de; Fernandes, P. B.; Müller, M. D.; Pires, M. de F. A.; Fernandes, E. N.; Xavier, D. F. Productive and nutritional traits of pasture in an agrosilvopastoral system, according to the distance from trees. Pesquisa Agropecuária Brasileira, v.46, p.1176-1183, 2011. https:// doi.org/10.1590/S0100-204X2011001000009

Santos, S. A.; Mcmanus, C.; Souza, G. S. e; Soriano, B. M. A.; Silva, R. A. M. S.; Comastri Filho, J. A.; Abreu, U. G. P.; Garcia, J. B. Variation in rectal and skin temperature of pantaneira and nelore cows and calves in the pantanal. Archivos de Zootecnia, v.54, p.237-244, 2005.

Silva, L. L. G. G. da; Resende, A. S. de; Dias, P. F.; Souto. S, M.; Azevedo, B. C. de; Vieira, M. S.; Colombari, A. A.; Torres, A. Q. A.; Matta, P. M. da; Perin, T. B.; Campello, E. F. C.; Franco, A. A. Diurnal ingestion behavior of crossbred heifers in a sylvanpastoral system in a tropical region. Archivos Latinoamericanos de Producción Animal, v.21, p.15-22, 2012.

Souza, W. de; Barbosa, O. R.; Marques, J. de A.; Costa, M. A. T.; Gasparino, E.; Limberger, E. Microclimate in silvipastoral systems with eucalyptus in rank with different heights. Revista Brasileira de Zootecnia, v.39, p.685-694, 2010. https://doi.org/10.1590/ S1516-35982010000300030 
Souza, P. T. de; Salles, M. G. F.; Araújo, A. A. de. Impact of heat stress on the physiology, reproduction and production of goats. Ciência Rural, v.42, p.1888-1895, 2012. https://doi.org/10.1590/S010384782012005000072
Tonini, H.; Morales, M. M.; Silva, V. P. da; Lulu, J.; Farias Neto, A. L. de. Effect of planting system and solar exposure on biomass allocation in the initial growth of eucalyptus. Ciência Florestal, v.29, p.86-95, 2019. https://doi.org/10.5902/1980509817808 